\title{
Effects of Different Topdressing Conditions on Photosynthetic Characteristics and Yield for Peanuts under Mulched Drip Irrigation
}

\author{
Huixin Wang ${ }^{1,2, a}$ \\ ${ }^{1}$ Shenyang Agricultural University \\ ${ }^{2}$ Liaoning Academy of Agricultural Sciences Shenyang, \\ China \\ 357904670@qq.com
}

\author{
Yifei $\operatorname{Liu}^{1, \mathrm{a}}$ \\ ${ }^{1}$ Shenyang Agricultural University \\ Shenyang, China \\ liuyifeiscience@163.com
}

\author{
Qiaobo Song $^{1}$ \\ ${ }^{1}$ Shenyang Agricultural University \\ Shenyang, China \\ 13889220763@163.com
}

\author{
Bing Guan ${ }^{1}$ \\ ${ }^{1}$ Liaoning Academy of Agricultural Sciences Shenyang, \\ China \\ 95174006@qq.com
}

a Joint first authors

\author{
Xiaori $\operatorname{Han}^{1, *}$ \\ ${ }^{1}$ Shenyang Agricultural University \\ Shenyang, China \\ hanxiaori@163.com
}

\author{
Qingwen Shi ${ }^{1}$ \\ ${ }^{1}$ Shenyang Agricultural University \\ Shenyang, China \\ feifan61@gmail.com
}

\footnotetext{
* Corresponding author
}

\begin{abstract}
The cropping patterns as drip irrigation under mulch were assumed in the experiment with peanut variety "Fu Hua 17" to study the effects of different topdressing on photosynthetic characteristics and yield for peanuts. Five different treatments were carried out to determine the photosynthetic characteristics, and a comprehensive evaluation was made in combination with the yields. The results showed that the diurnal changes for $\mathrm{T1}(\mathrm{PK}+\mathrm{Ca})$ and $\mathrm{T} 2(\mathrm{~N}+\mathrm{Ca})$ in the photosynthetic rate were lower than those in $\mathrm{T} 3(\mathrm{~N}+\mathrm{PK})$ and $\mathrm{T} 4 \mathrm{(N+PK}+\mathrm{Ca})$, a fact illustrating that $N, P$ and $K$ elements have a direct impact on peanut photosynthetic rate, chlorophyll SPAD value of the three treatments continued to decline at the beginning of flowering, which means that leaf chlorosis and fertilizer shortage appeared earlier for peanuts in the middle and late period. The sequence of yield was: $\mathrm{T} 4(\mathrm{~N}+\mathrm{PK}+\mathrm{Ca})>\mathrm{T} 3$ $(\mathrm{N}+\mathrm{PK})>\mathrm{T} 2(\mathrm{~N}+\mathrm{Ca})>\mathrm{T} 1(\mathrm{PK}+\mathrm{Ca})>\mathrm{T} 5(\mathrm{CK}$ without topdressing). $\mathrm{T} 4$ yield was slightly higher than $\mathrm{T3}$, a result showing with sufficient NPK, increasing Ca fertilizer could increase yield and efficiency. The studied results could offer theoretical basis for revealing the yield increasing mechanism of integrated management of water and fertilizer under mulched drip irrigation.
\end{abstract}

Keywords-peanut; drip irrigation; photosynthetic characteristics; yield

The peanuts production mainly depends on photosynthesis, and peanuts photosynthesis capacity is not only related to their own intrinsic factors, but also related to such external factors as illumination intensity, $\mathrm{CO} 2$ concentration, temperature, humidity, fertilizer and water[1-3]. According to some researches, nitrogen, as the necessary mineral element of chlorophyll biosynthesis, will have a direct impact on the enzyme content; phosphorus and potassium will stimulate the transfer and transport of photosynthates, thus affecting photosynthesis in an indirect way. Planting mode could improve population structure and soil micro-environment, and shall directly or indirectly affect photosynthesis, and therefore exert impacts on the production.

Drip irrigation origins from Israel in the 1960s. In the 1990s, Xinjiang succeeded in the drip irrigation experiment for field cotton[7-9]. In 2011, drip irrigation technology was adopted for peanuts planting in sandy semiarid region in northwest Liaoning province, China. At present, many researchers have already completed a series of studies on drip irrigation planting technology and translocation of water and fertilizer, but they are mostly on cottons and fruit trees. There are few researches on translocation rule and yield-increasing mechanism for peanuts with fertilization under mulched drip irrigation in the local area, especially without intensive studies on photosynthetic physiological characteristics. This article, whose focus is on peanut cultivation in sandy semiarid region under mulched drip irrigation, will prove to be thorough studies about impacts on peanut photosynthesis characteristics and chlorophyll content with the different topdressing under fertilization, while in combination of harvest fluctuation features for further analytic demonstration, all of which shall serve as theoretical reference for more detailed research on drip irrigation for peanut growth and physiological changes impact, most important to the further discovery of peanut yield increase under drip irrigation with fertilization[10-12]. 


\section{MATERIALS AND METHODS}

\section{A. General situation of test area}

The experiment was conducted at Zhanggutai test station of Liaoning Academy of Agricultural Sciences, with the conditions as north latitude $42^{\circ} 42^{\prime}$, east longitude $122^{\circ} 32^{\prime}$, altitude $213.1 \mathrm{~m}$, loam soil for farming, organic matter content of $27.4 \mathrm{~g} / \mathrm{kg}$, available nitrogen $143 \mathrm{mg} / \mathrm{kg}$, phosphorus $66.0 \mathrm{mg} / \mathrm{kg}$, potassium $108 \mathrm{mg} / \mathrm{kg}$, pH value of 5.6. In this area, frost-free period is 150 155 days, with accumulated temperature $\left(\geqslant 10^{\circ} \mathrm{C}\right)$ as $3468^{\circ} \mathrm{C}$, annual average temperature as $6.82^{\circ} \mathrm{C}$. The annual average rainfall is 500 520mm, mostly focused in July and August, and the annual average evaporation is $1600 \sim 1800 \mathrm{~mm}$. Dryness is about 4.0 , as that in a semi arid region, where spring drought, summer drought and autumn hanging occurs, or spring drought, summer drought and autumn hanging occurs alternately.

B. Research design and methods

Cropping patterns as drip irrigation under mulch was adopted for such an experiment, with the detailed description as furrow top width of $65 \mathrm{~cm}$, ridge furrow bottom width of $95-100 \mathrm{~cm}, 10 \mathrm{~cm} \sim 12 \mathrm{~cm}$ high, two rows for furrow planting with row spacing of $35 \mathrm{~cm}$, where in the dripping belts were paved, row spacing of $8 \sim 10 \mathrm{~cm}$ for precise sowing of a single seed[13-14], and the planting density was 14,000 plants per $667 \mathrm{~m} 2$. The drip fertilization period is the flowering stage (early July) and pod swelling stage (early August) respectively, with irrigation amount as $10 \mathrm{~m} 3 / 667 \mathrm{~m} 2$ times, drip irrigation fertilizer: urea $(\mathrm{N})$, phosphorus and potassium (PK), Calcium nitrate $(\mathrm{Ga})$ for 5 treatments as specified, of which $\mathrm{T} 5$ is as the control without topdressing (see Table 1). Each cell is $25 \mathrm{~m}$ long and $4 \mathrm{~m}$ wide, three times repeated.

Coated mechanical seeding was conducted in mid May, 2014 , with fertilization as organic fertilizer $3000 \mathrm{~kg} / 667 \mathrm{~m} 2$, peanut release fertilizer $50 \mathrm{~kg} / 667 \mathrm{~m} 2$, peanut-specific fertilizer $10 \mathrm{~kg} / 667 \mathrm{~m} 2$, multi-micronutrient fertilizer $1 \mathrm{~kg} /$ $667 \mathrm{~m} 2$ before sowing. Tested variety is Fu Hua17.

TABLE 1 DIFFERENT FERTILIZER APPLICATION RATES FOR PEANUTS UNDER MULCHED DRIP IRRIGATION

\begin{tabular}{|c|c|c|c|c|}
\hline \multirow[b]{2}{*}{$\begin{array}{l}\text { The experimental } \\
\text { plot number }\end{array}$} & \multirow[b]{2}{*}{ Treatment } & \multicolumn{3}{|c|}{ Fertilizer amount（kg/667m2.times） } \\
\hline & & $\begin{array}{l}\text { Urea } \\
(\mathrm{N})\end{array}$ & $\begin{array}{c}\text { Potassium } \\
\text { dihydrogen } \\
\text { phosphate } \\
(\text { PK })\end{array}$ & $\begin{array}{l}\text { Calcium nitrate } \\
\text { (Ga) }\end{array}$ \\
\hline $\mathrm{T} 1$ & Nitrogen free plot $(\mathrm{PK}+\mathrm{Ca})$ & 0 & 3 & 2 \\
\hline $\mathrm{T} 2$ & phosphorus potassium free plot $(\mathrm{N}+\mathrm{Ca})$ & 5 & 0 & 2 \\
\hline $\mathrm{T} 3$ & Calcium nitrate free plot $(\mathrm{N}+\mathrm{PK})$ & 5 & 3 & 0 \\
\hline $\mathrm{T} 4$ & $\mathrm{~N}+\mathrm{PK}+\mathrm{Ca}$ plot & 5 & 3 & 2 \\
\hline $\mathrm{T} 5$ & No fertilizer plot $(\mathrm{CK})$ & 0 & 0 & 0 \\
\hline
\end{tabular}

\section{Research methods}

\section{1) Measurement of photosynthetic indicators}

In the peanut swelling development period (mid August), we used portable Licor-6400 photosynthesis system (manufactured by American LI - COR company) to measure the net photosynthetic rate $\left(\mathrm{Pn}, \mu \mathrm{mol} \cdot \mathrm{m}^{-2} \cdot \mathrm{s}^{-1}\right)$, transpiration rate $\left(\mathrm{Tr}, \mathrm{mmol} \cdot \mathrm{m}^{-2} \cdot \mathrm{s}^{-1}\right)$ and other major physiological and environmental factors for these peanuts. Testing duration was from 8:00 to 18:00, as measured once every 2 hours. We selected healthy plants with similar growth, as well as those healthy leaves with full stretch, free from pests and diseases in the test. Each indicator were measured for 3 repetitions, 3 data for each repetition before the average was taken.

\section{2) Measurement of chlorophyll content}

Fine windless weather was selected respectively in peanut seedling growth, flowering, pegging stage, pod swelling and maturity period, and then a hand-held portable SPAD.502 chlorophyll meter made in Japan was used to measure SPAD values in vivo for leaves, which were selected from each plot to determine their photosynthetic parameters. In the test, we need to avoid vein, and we only take the average value of the bottom, middle and top leaves.

3) Data analysis

Experimental data variance analysis, correlation analysis and other statistical analysis are analyzed with SPSS software, while charts were processed with Excel software.

\section{RESULTS AND ANALYSIS}

\section{A. Impacts from drip fertilization on diurnal changes of peanut photosynthetic rate}

It can be seen from Fig .1 that there is a bimodal curve obviously for peanut diurnal variations of T1, T2 and T5. The big peak is from 10:00 to 12:00 roughly, a trough at about 14:00, and a small peak at 16:00, but there is no a significant downturn for $\mathrm{T} 3$ and $\mathrm{T} 4$ at 14:00.The photosynthetic rate of $\mathrm{T} 4$ reaches 22.45 at 12:00, 17.7 at 16: 00, while there is no remarkable difference between T3 and T4 in terms of diurnal variations of photosynthetic rate, a fact meaning that for the moment, there is no direct impact on peanut photosynthetic rate with Ga fertilizer. Diurnal variations of $\mathrm{T} 1$ and $\mathrm{T} 2$ were equally lower than those of T3 and T4, a fact making it clear that NPK elements have a direct impact on peanut photosynthetic 
rate. Photosynthetic rate changes throughout the day for T5 are always at a lower level, indicating that if NPK fertilizer is not applied timely for peanuts in the middle and late period, the photosynthetic rate for peanuts shall be significantly impacted, thereby affecting the yield formation.

\section{B. Impacts from drip fertilization on diurnal changes of peanuts transpiration rate}

It can be seen from Table 2 that with the light radiation enhancement, peanuts enjoy vigorous physical activity, and their transpiration rate is enhanced with the photosynthetic rate increase as the temperatures rise. A trough appeared around 14:00, and the transpiration rate for T1, T2 and T5 declined remarkably, 4.10, 4.23, and 3.02 respectively, for with the further temperature rise, leaf stomate partially closed in order to reduce water loss. With the fall of temperature and relative humidity increase around 16:00, the transpiration rate rose slightly, and then gradually decreased. The highest value of T3 and T4 appears at 12:00, 9.80 and 9.23 respectively, and then both slowly dropped.

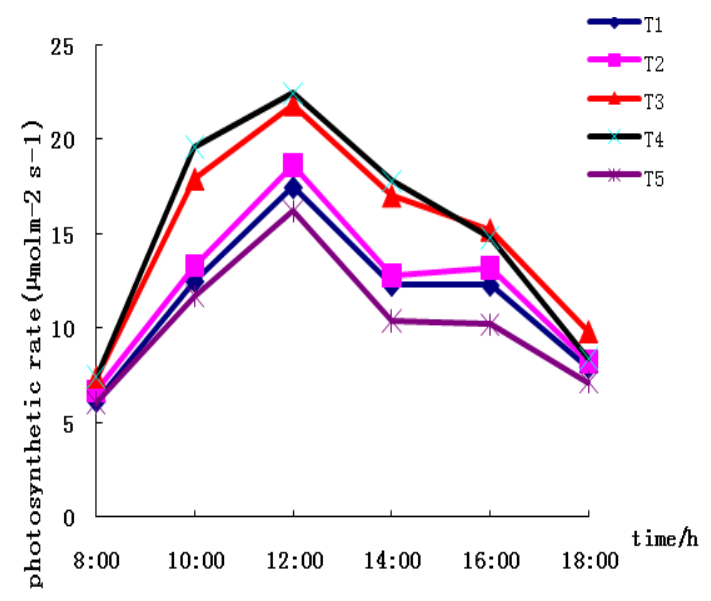

Figure 1: changes of peanuts daily photosynthetic rate with different processing

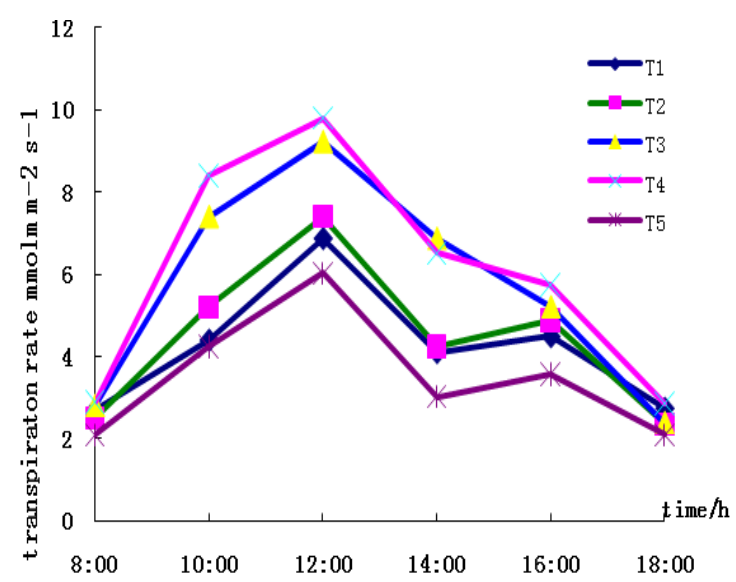

Figure 2:changes of peanuts daily transpiration rate with different processing

\section{Impacts from drip fertilization on peanuts chlorophyll content}

It can be seen from Fig .3 (peanut SPAD dynamic changes), there is no significant difference in chlorophyll content due to consistent management for each treatment in the seedling and flowering period, but there is significant difference in peanuts chlorophyll content due to topdressing twice in the middle and late period. The chlorophyll content for T3 and T4 during the pegging and pod swelling period remained higher, with SPAD value equally above 40 till pod swelling period and and a fall till maturity period. However, chlorophyll content for the other three treatments continued to decline at the beginning of flowering, of which T5 showed the most significant drop.

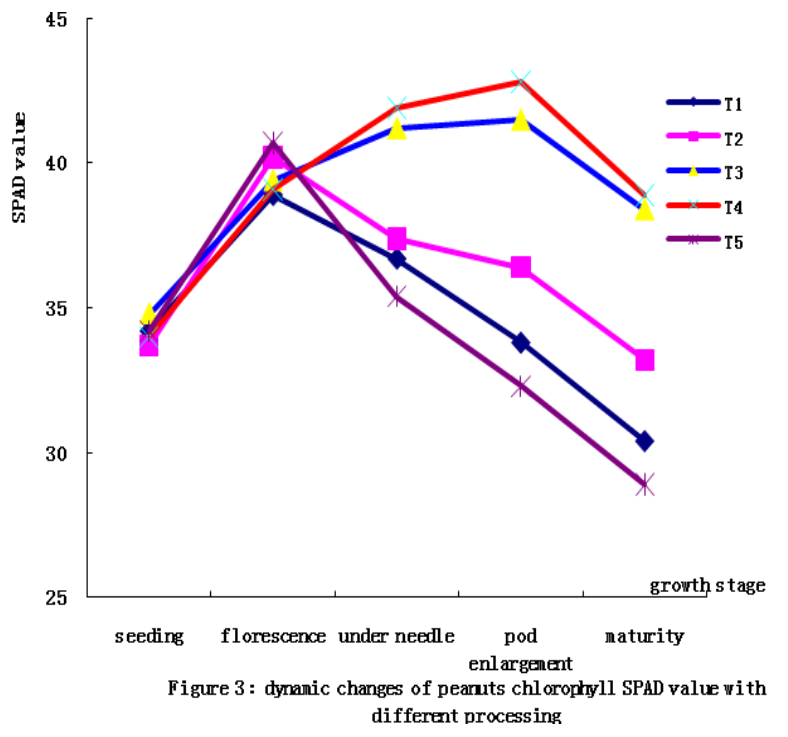

\section{Impacts from drip fertilization on differences peanut yields}

It can be seen from Table 2 that peanuts enjoy better agronomic traits under T3 and T4 conditions, of which the T4 yield is the highest, $321.5 \mathrm{~kg} / 667 \mathrm{~m} 2$, and T3 yield is $313.8 \mathrm{~kg} / 667 \mathrm{~m} 2$, so compared with other treatments, their agronomic traits and yield gap are much striking. T1 and $\mathrm{T} 2$ yield are significantly lower than those of T3 and T4, for $\mathrm{N}$ fertilizer was applied separately to $\mathrm{T} 1$ in the middle and late period, and there is lack of PK fertilizer, which plays a catalytic role in the transport and transformation of photosynthetic products, exerting indirect effects on photosynthesis, and thereby affecting. Due to the lack of $\mathrm{N}$ fertilizer application in the middle and late period for $\mathrm{T} 2$, yield development was affected, for $\mathrm{N}$ is the prime nutrients necessary for chlorophyll synthesis product, and it has a direct impact on the content of related enzymes, affecting the yield accordingly.

\section{CONCLUSION AND DISCUSSION}

A. A bimodal curve appeared for the peanuts photosynthetic rate and diurnal changes for T1, T2 and T5 with a trough at 14:00, for the reason that at this time, the stronger illumination intensity and relatively high temperature made the leaves close their stomatas, 
preventing $\mathrm{CO} 2$ entering the blades. Meanwhile due to the lack of water for blades, photosynthates output slowed down. Nevertheless, there was no obvious trough for T3 and T4 at 14:00, and the reason could be that NPK and other nutrients are relatively sufficient for these two treatments. Some research shows that nitrogen is the dominant component for protein and nucleic acid, and they are the fundamentals of live activities and basic structure of cell protoplasm. Nitrogen also exists in enzyme and many vitamins, while enzyme is highly needed in every metabolism step for peanuts. Additionally phosphorus and potassium are involved in each metabolism process for crops, of which potassium features its speedy flow through

TABLE II. PEANUT AGRONOMIC TRAITS AND YIELD PERFORMANCE OF DIFFERENT TREATMENT

\begin{tabular}{ccccccccc}
\hline mode & $\begin{array}{c}\text { main } \\
\text { stem } \\
\text { height } \\
(\mathbf{c m})\end{array}$ & $\begin{array}{c}\text { branch } \\
\text { length } \\
(\mathbf{c m})\end{array}$ & $\begin{array}{c}\text { total number } \\
\text { of branches } \\
\text { (Article } / \\
\text { plant) }\end{array}$ & $\begin{array}{c}\text { Pod } \\
\text { number } \\
\text { (number/ } \\
\text { Plant) }\end{array}$ & $\begin{array}{c}\text { Single plant } \\
\text { productivity } \\
(\mathbf{g})\end{array}$ & $\begin{array}{c}\text { Hundred } \\
\text { weight } \\
(\mathbf{g})\end{array}$ & $\begin{array}{c}\text { Hundred } \\
\text { kernel } \\
\text { weight } \\
(\mathbf{g})\end{array}$ & $\begin{array}{c}\text { Kg/667m2 } \\
\text { volume }\end{array}$ \\
\hline T1 & $29.5 \mathrm{c}$ & $34.8 \mathrm{c}$ & $7.3 \mathrm{~d}$ & $17.3 \mathrm{c}$ & $17.4 \mathrm{c}$ & $174.3 \mathrm{c}$ & $72.8 \mathrm{c}$ & $248.6 \mathrm{bc}$ \\
$\mathrm{T} 2$ & $32.1 \mathrm{~b}$ & $36.7 \mathrm{~b}$ & $8.3 \mathrm{c}$ & $16.7 \mathrm{c}$ & $17.9 \mathrm{~b}$ & $173.6 \mathrm{c}$ & $72.5 \mathrm{c}$ & $253.1 \mathrm{~b}$ \\
$\mathrm{~T} 3$ & $35.2 \mathrm{a}$ & $38.5 \mathrm{ab}$ & $9.3 \mathrm{~b}$ & $23.0 \mathrm{~b}$ & $22.3 \mathrm{a}$ & $191.2 \mathrm{~b}$ & $74.1 \mathrm{~b}$ & $313.8 \mathrm{a}$ \\
$\mathrm{T} 4$ & $36.4 \mathrm{a}$ & $38.7 \mathrm{a}$ & $10.3 \mathrm{a}$ & $24.7 \mathrm{a}$ & $22.9 \mathrm{a}$ & $202.6 \mathrm{a}$ & $75.4 \mathrm{a}$ & $321.5 \mathrm{a}$ \\
$\mathrm{T} 5$ & $28.4 \mathrm{c}$ & $33.0 \mathrm{c}$ & $6.3 \mathrm{e}$ & $9.0 \mathrm{e}$ & $16.9 \mathrm{c}$ & $160.2 \mathrm{~d}$ & $70.4 \mathrm{~d}$ & $238.1 \mathrm{c}$ \\
\hline
\end{tabular}

the biofilm, and widely affects the peanuts growth and metabolism[1,8]. Potassium has strong links with photosynthesis and carbohydrate accumulation, and it can stimulate low molecular compounds (amino acids, monosaccharide, and fatty acid) to convert into high molecular compounds (protein, starch, fat, and fiber), accelerating the transfer of assimilate to storage organs. When there is an absence of potassium, disaccharide and starch would be hydrolysed to monosaccharide, which stays in blade and affects the efficiency of peanuts photosynesis and pod plumpness. Phosphorus is able to strengthen crop drought resistance. Balanced topdressing of NPK nutrients for T3 and T4 achieves lush plant growth and well-developed roots, when relatively adequate moisture shall be available to accelerate transpiration rate, thus preventing withered leaves and stomatal closure, rather influential on photosynthesis. This is also why there is no obvious trough in $\mathrm{T} 3$ and $\mathrm{T} 4$ transpiration rate.

B. Nitrogen is also a very important ingredient for chlorophyll, while the amount of chlorophyll shall directly affect the carbohydrate synthesis amount, and it is also related to peanuts growth and yield[8]. When there is a lack of nitrogen for peanuts, the formation of chlorophyll will be checked, and chlorosis appears on leaves, leading to decreased photosynthesis and carbohydrate synthesis amount[9]. The chlorophyll SPAD value of such treatments as T1, T2 and T5 continuously declined during florescence, for the reason that peanuts are the type of plants as blossoming on the ground and fruiting under the ground, and they need a lots of fertilization and water in the mid and late period, but the sandy land is weak in retaining water and fertilizer, so if nutrients are not applied in time during such periods, fertilizer shortage shall arise and chlorosis for peanut leaves and premature shall be easily sensed. Though nitrogen topdressing was available for T2, there was still a lack of PK elements all the while in the middle and late period. Some studies concerned have shown that phosphorus is the main element for many organic plants, for it stimulates crop flower bud differentiation, cutting down plant growth period. Potassium, helpful to protein synthesis, is an activators of many enzymes, so if there is sufficient potassium, peanut plants can absorb more nitrogen for faster synthesis rate of protein[16]. Therefore, when $\mathrm{T} 2$ is applied with nitrogen fertilizer only, the diversified needs of peanuts nutrition elements cannot still be satisfied thoroughly.
C. The yields for five treatments from the highest to the lowest are in such an order: $\mathrm{T} 4(\mathrm{~N}+\mathrm{PK}+\mathrm{Ca})>\mathrm{T} 3$ $(\mathrm{N}+\mathrm{PK})>\mathrm{T} 2(\mathrm{~N}+\mathrm{Ca})>\mathrm{T} 1(\mathrm{PK}+\mathrm{Ca})>\mathrm{T} 5(\mathrm{CK}$ without topdressing). Research shows that calcium is good for carbohydrate transformation and nitrogen metabolism, so sufficient calcium can help the peanuts absorb nitric nitrogen, and peanuts can only use liquid ammonia in lack of calcium[16]. Calcium can also strengthen cells and stimulate the pod formation. Thus, T4 enjoys slightly greater yield than T3, but it can definitely boost more economic benefits in mass production. As a result, in the middle and late period of peanuts growth, under the condition of sufficient NPK, increasing Ca fertilizer can achieve the yield increase and profit improvement.

\section{ACKNOWLEDGMENT}

The research work was supported by National Natural Science Foundation of China under Grant No. 31301842, Key Project of Science and Technology of Liaoning under Grant No. 2014201007, China Postdoctoral Science Foundation under Grant No. 2012M510839 and 2014T70262, the Doctoral Scientific Fund Project of the Ministry of Education of China under Grant No. 20122103120011, Cultivation Plan for Youth Agricultural Science and Technology Innovative Talents of Liaoning Province under Grant No. 2014043, National Natural Science Initial Foundation of Shenyang Agricultural University under Grant No. 20112013, Postdoctoral Science Foundation of Shenyang Agricultural University under Grant No. 105110, Tianzhu mountain talents support program of SYAU and the Earmarked Fund for China Agriculture Research System under Grant No. CARS-14.

\section{REFERENCES}

[1] Wan Shubo. Chinese peanut cultivation. Shanghai Science and Technology Press, 2003.

[2] [2] Liu YF, Han XR, Zhan XM, Yang JF. Regulation of calcium on peanut photosynthesis under low night temperature stress. J. Integra. Agric. 12, pp. 2172-2178, 2013.

[3] [3] Peng Xiaobang, Cai Jing. Photosynthetic physiological haracteristics of soybean and pepper in agro forestry systems of Weibei loess area . Journal of Ecology. 6, pp. 3173-3180, 2009

[4] [4] Cheng-yuan Xu.Shahla Hosseini-Bai. Effect of biochar amendment on yield and photosynthesis of peanut on two types of soils. Environ Sci Pollut Res, 7, pp. 9-14, 2010.

[5] [5] Abou Kheira AA . Macromanagement of deficit-irrigated peanut with sprinkler irrigation. Agric Water Manag. 96, pp. 1409-1420, 2009 
[6] [6] Liu YF, Qi HY, Bai CM, et al. Grafting helps improve photosynthesis and carbohydrate metabolism in leaves of muskmelon. Int. J. Biol. Sci. 7, pp. 1161-1170, 2011.

[7] [7] Li Qinghua. Factor analysis about peanut agronomic yield traits in different habitats. Peanut journal., 38, pp. 36-40, 2009.

[8] [8] Su Junwei,Yu Hongbo Liao Ning Peanut. Beijing: China Agricultural Science and Technology Press, 2012.

[9] [9] Chen Baoyan ,Ma Xingwang, The influence of cotton drip irrigation SPAD value and yield by different strategies applied $\mathrm{N}$. Chinese Agricultural Science Bulletin. 27, pp. 124-129, 2011.

[10] [10] Bandyopadhyay PK, Mallick S, Rana SK. Water balance and crop coefficients of summer-grown peanut(Arachis hypogaea L.) in a humid tropical region of India. Irrig Sci. 23, pp. 161-169, 2005.

[11] [11] Liu YF, Li TL, Qi HY, et al. Effects of grafting on carbohydrate accumulation and sugar-metabolic enzyme activities in musk-melon. Afr. J. Biotechnol. 9(1), pp. 25-35, 2010.
[12] [12] Jongrungklang N, Toomsan B, Vorasoot N, Jogloy S, Boote KJ, Hoogenboom G, Patanothai A. Rooting traits of peanut genotypes with different yield responses to pre-flowering drought stress. Field Crop Res. 120, pp. 262-270, 2011.

[13] [13] Wu Zhanpeng, Su Junwei, Wang Huixin. Development of anti-erosion coating peanut planter. China Oil Crop journal. 35, pp. 360-363, 2013.

[14] [14] Wang Huixin, Wu Zhanpeng. Semiarid region peanut planting suitable single and double precision sowing grain Density. China Oil Crop journal. 35, pp. 92-96, 2013.

[15] [15] Mamoru Nango, Miwa Sugiura. Photosynthesis and artificial photosynthesis research. Res Chem Int. 40, pp. 3163-3168, 2014.

[16] [16] Zhang H C, Yin W L, Xia X L. The Mechanism of Ca2+ signal transduction under abiotic stresses in plants. Chinese Bulletin of Botany, 24, pp. 114-122, 2007. 